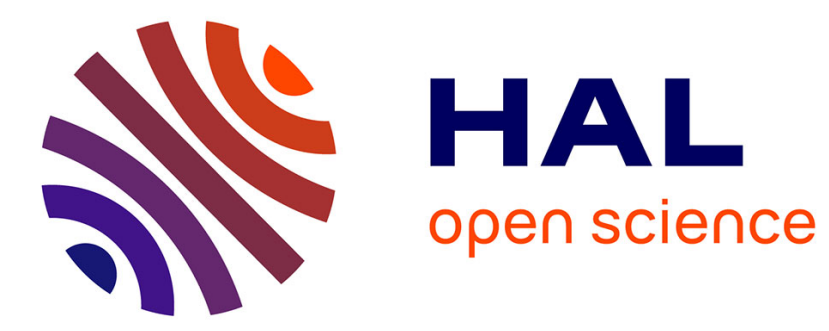

\title{
Patterns of ash (Fraxinus excelsior L.) colonization in mountain grasslands: the importance of management practices
}

\author{
Marie-Pierre Julien, Alard Didier, Gerard Balent
}

\section{To cite this version:}

Marie-Pierre Julien, Alard Didier, Gerard Balent. Patterns of ash (Fraxinus excelsior L.) colonization in mountain grasslands: the importance of management practices. Plant Ecology, 2006, 183 (1), pp.177-189. 10.1007/s11258-005-9019-x . hal-01360582

HAL Id: hal-01360582

https://hal-univ-tlse2.archives-ouvertes.fr/hal-01360582

Submitted on 6 Sep 2016

HAL is a multi-disciplinary open access archive for the deposit and dissemination of scientific research documents, whether they are published or not. The documents may come from teaching and research institutions in France or abroad, or from public or private research centers.
L'archive ouverte pluridisciplinaire HAL, est destinée au dépôt et à la diffusion de documents scientifiques de niveau recherche, publiés ou non, émanant des établissements d'enseignement et de recherche français ou étrangers, des laboratoires publics ou privés. 


\title{
Patterns of ash (Fraxinus excelsior L.) colonization in mountain grasslands: the importance of management practices
}

\author{
Julien Marie-Pierre ${ }^{1, *}$, Alard Didier $^{2}$ and Balent Gérard ${ }^{1}$ \\ ${ }^{1}$ UMR 1201 DYNAFOR INRA-INPT/ENSAT, Chemin de Borde Rouge, INRA (National Institute of Research \\ in Agronomy) - Centre de Toulouse, BP 5627, F-31326, Castanet-Tolosan cedexFrance; ${ }^{2}$ UMR INRA 1202 \\ BIOGECO, Ecologie des communautés, Université de Bordeaux 1, Avenue des Facultés, F-33405, Talence; \\ *Author for correspondence (e-mail:mjulien@toulouse.inra.fr; fax: + 33561285411; phone: + 33561285346)
}

Received 21 January 2005; accepted in revised form 28 June 2005

Key words: Cutting, Grazing, Herbaceous biomass, Heterogeneity, Seedling establishment, Vegetative reproduction

\begin{abstract}
Woody colonization of grasslands is often associated with changes in abiotic or biotic conditions or a combination of both. Widely used as fodder and litter in the past traditional agro-pastoral system, ash (Fraxinus excelsior L.) has now become a colonizing species of mountain grasslands in the French Pyrenees. Its present distribution is dependent on past human activities and it is locally controlled by propagule pressure and abiotic conditions. However, even when all favourable conditions are met, all the potentially colonizable grasslands are not invaded. We hypothesize that management practices should play a crucial role in the control of ash colonization. From empirical field surveys we have compared the botanical composition of a set of grasslands (present and former) differing in management practices and level of ash colonization. We have displayed a kind of successional gradient positively linked to both ash cover and height but not to the age of trees. We have tested the relationships between ash presence in grassland and management types i.e. cutting and/or grazing, management intensity and some grassland communities' features i.e. total and local specific richness and species heterogeneity. Mixed use (cutting and grazing) is negatively linked to ash presence in grassland whereas grazing alone positively. Mixed use and high grazing intensity are directly preventing ash seedlings establishment, when low grazing intensity is allowing ash seedlings establishment indirectly through herbaceous vegetation neglected by livestock. Our results show the existence of a limit between grasslands with and without established ashes corresponding to a threshold in the intensity of use. Under this threshold, when ash is established, the colonization process seems to become irreversible. Ash possesses the ability of compensatory growth and therefore under a high grazing intensity develops a subterranean vegetative reproduction. However the question remains at which stage of seedling development and grazing intensity these strategies could occur.
\end{abstract}

\section{Introduction}

Woody colonization is a rather general trend experienced by many temperate and tropical grasslands (Archer et al. 1988; Prach et al. 1996; Van Auken 2000; Roques et al. 2001; Moleele et al.
2002). This phenomenon has an important impact on grassland structure (Hooper and Vitousek 1997) and is a major cause of habitat fragmentation and species extinction (Lett and Knapp 2003). The driving factors of woody colonization are largely debated to be either linked to changes in abiotic 
conditions or in biotic conditions or a combination of both (Van Auken 2000). Grasslands are subject to woody colonization associated with variations in climate (O'Connor 1994), fire regime (Skowno et al. 1999; Lett and Knapp 2003), and grazing (Brown and Archer 1989; Brown et al.1998; Briggs et al. 2002). The invasion or colonization process of a new site by a native or exotic species is generally the result of three successive stages: arrival, establishment and expansion (Williamson 1996). Arrival stage depends mainly on the quantity of seeds produced within the surrounding landscape, on the ability of the seeds to disseminate and on filtering capacity of the surrounding landscape (i.e. propagule pressure). Establishment and expansion stages depend on local factors (environmental and management) which may influence the performances of the invader (Rouget and Richardson 2003). At local scales, the intrinsic characteristics of the invader, i.e. its biological traits and geographic origin, play also an important role in the colonization process (Moyle and Light 1996; Williamson and Fitter 1996).

Woody colonization in grasslands is a major issue in European mountainous areas (Prach et al. 1996; Prévosto et al. 2003; Pasche et al. 2004), where it is often linked to changes in land uses (Garcia-Ruiz et al. 1996; Austrheim et al. 1999; MacDonald et al. 2000). In Central Pyrenees, grasslands are colonized by a single native tree species: the ash (Fraxinus excelsior L.) which was used, as a multifunctional resource for forage, litter, firewood and tools, in the ancient agro-pastoral systems (Gibon and Balent 2004). It was therefore planted as hedgerow tree along the rivers, and to separate adjacent hay meadows, or by small groups around the barns to provide winter fodder to the animals. As a consequence, the presence or absence of ash within the different landscape patches at the Pyrenean scale is largely determined by these past human activities.

Within the landscape units where ashes have been planted for pastoral purpose, the propagule pressure for this species is supposed to be high and fairly distributed because of both ash spatial distribution and ability to produce important amount of wind disseminated seeds (Marigo et al. 2000).

When ash is present, it is found in two kinds of parcels: ash woodlands in the form of dense pole stage which are actually former grasslands or permanent grasslands in the form of encroached trees. Despite all grasslands parcels with good soil conditions are a potential target area to ash colonization they are not all invaded. Such contrasts in colonization patterns may be explained by local management factors. We hypothesise that the establishment and the expansion stages of the colonization process may be influenced by such factors through rules of external deletion or internal assembly rules (Keddy 1992; Lodge 1993; Belyea and Lancaster 1999). Thus, management practices may remove directly the invader by the mean of a high disturbance rate or may indirectly control invader through the features of the grassland community affecting its invasibility.

Our study focuses on the patterns of the current ash distribution in present and former grasslands and on the factors which may explain such patterns. It is based on the comparative analyses of a set of parcels at different visual stages of colonization (i.e. from grasslands with tree established to ash young woodlands). We intend to reconstitute a chronosequence of ash colonization, from establishment to expansion and to detect whether differences in management practices may explain differences in patterns of ash distribution.

In order to evaluate the importance of indirect control of ash colonization we investigated potential factors such as size of parcels, and grassland community features and their possible interaction with management practices. We assume that the study of these present patterns will help to identify the key factors affecting the different stages of the colonization process.

\section{Material and methods}

\section{Study site}

This study was performed in the peripheral area of the National Park of the Pyrenees (PNP) in the municipality of Villelongue $\left(00^{\circ} 03^{\prime} \mathrm{W}\right.$ and $\left.42^{\circ} 57^{\prime} \mathrm{N}\right)$ where the farm number decreased from 18 to 6 between 1988 and 2002. This decline of the agricultural and pastoral activities was accompanied by land use changes and parcels abandonment.

This municipality is located in a small valley of medium altitudinal range (500-1800 $\mathrm{m}$ a.s.1.). For the period 1983-2001, the mean annual temperature was $12.5^{\circ} \mathrm{C}\left(6^{\circ} \mathrm{C}\right.$ for January and 
$20{ }^{\circ} \mathrm{C}$ for August) and the mean annual precipitations was $77.1 \mathrm{~mm}(60.9 \mathrm{~mm}$ for July and $111.3 \mathrm{~mm}$ for April) (data from METEO France). Slopes are locally steep (up to $50^{\circ}$ ) with rocky outcrops and marked slopes along the two streams delimiting the municipality boundaries. Geologically, the site is in a large Palaeozoic anticline structure. The quaternary formations are present in forms of glacial deposits and lacustrine alluvium (Barrère et al. 1980). The description and the physicochemical analyses on 20 representative parcels of the studied area indicate that most of the soils are brunisols (Duchaufour 1983; Baize and Girard 1995) derived from the solifluction of glacial schist deposits (Barrère et al. 1980). Surface horizons present a silty-sandy dominant texture and slightly acid ( $\mathrm{pH}$ between 5.4 and 6.4 with a mean of 6.1). Organic matter is high (between $5 \%$ and $17.6 \%$ with a mean of $11.7 \%$ ), the rate of mineralization also (between $9.5 \%$ and $15.5 \%$ with a mean of $11.3 \%$ ) and biological activity is important (many earthworms casts and molehills, the root system is well developed). In our study, we consider soils to be homogeneous. They don't constitute an environment filter to ash colonization process.

\section{Sampling design}

Botanical composition of 96 parcels has been recorded between June and July 2002. Sampling was stratified according to a visual evaluation of the degree of ash colonization in these parcels in order to build a chronosequence. 90 parcels correspond to permanent grasslands with presence or absence of ash and 6 parcels of former grasslands which correspond currently to ash woodlands in the form of dense pole stage (Photo 1a). Among the 90 permanent grasslands, 65 are without ash, 6 are with ash seedlings and 19 are with established ash trees (Photo 1b).

In order to cover a broad range of situations, we included in our sample a diversity of present management practices which are mowing and grazing (named mixed use in the rest of the text), grazing alone and abandonment (data documented through a municipality farm survey, pers. comm., Mottet 2004). The hay-cutting is done yearly at the same period with slight adjustment to weather conditions i.e. from the beginning of June to the middle of July in the parcels located between 500 and $900 \mathrm{~m}$ a.s.1. and around mid July in the parcels located between 1000 and $1200 \mathrm{~m}$ a.s.l. All the parcels are grazed by cattle herds except for two parcels grazed by both sheep and goats. The parcel area ranges from 0.1 to 3.5 ha with an average of 0.75 ha.

\section{Botanical composition and community features}

Botanical composition has been recorded using the point quadrat analysis method (Daget and Poissonet 1971; Stampfli 1991). The method consists in 50 punctual observations along a $20 \mathrm{~m}$ long transect (i.e. one observation every $40 \mathrm{~cm}$ ). Edge effects and undesired environmental heterogeneity (e.g. rock outcropping, dung patches) were carefully avoided when localising transect in the parcel. Under these conditions, the transect line is considered to be representative of the whole parcel diversity (Daget and Poissonet 1971). For each of the 50 points, the presence of a given plant species is noted when the species foliage contacts a steel needle stuck vertically in the ground. The steel needle is $1 \mathrm{~m}$ length and $0.5 \mathrm{~cm}$ in diameter. For every point, we identified species by starting with the species of the upper layer of the canopy and then the species of the lower layers. We took care, when recording one point, to keep the vegetation of the next observation undisturbed.

Species abundance is considered to be the sum of all the presence recorded along a transect (i.e. abundance ranges between 0 and 50). Several indices accounting for the community structure were calculated for each transect: the total species richness (TSR), the average species richness by point, accounting for local richness (LR) and the number of points needed to capture half specific richness (SR50). This last index is an indirect measure of community heterogeneity (Lauga and Joachim 1987) presenting low values for homogeneous vegetation and high values for heterogeneous one.

Nomenclature follows Flora Europaea (Tutin et al. 1983).

\section{Ash description in parcels}

Ash relative abundance has been estimated from point quadrat analysis in the 96 parcels. Ash 

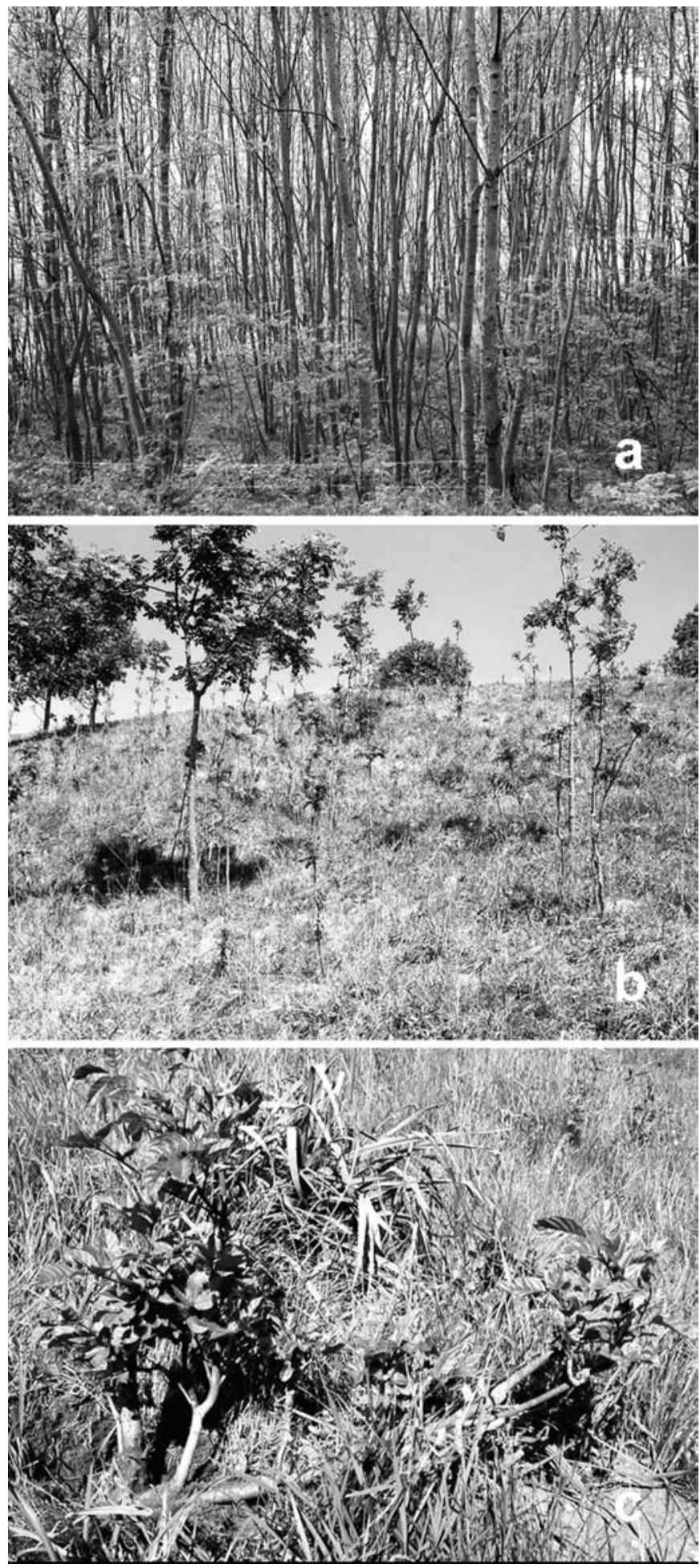

Photo 1. Parcels with established ashes. (a) Ash woodland (b) Grassland with established trees (c) Ash 'tree' with suckers. 
density, age and height have been measured only on $23 / 25$ parcels where measurable ash trees were present in 2002 i.e. saplings to mature trees, two parcels with established ash trees being cleared before tree measurement. For density measurement all the ashes have been counted within a rectangular area of $50 \mathrm{~m}^{2}(10 \times 5 \mathrm{~m})$. Ash density is expressed in number of ashes per hectare. Tree height and age have been estimated respectively from direct height tree measurement and number of annual rings in cross section or core sample from 10 individuals trees representing the observable diversity of tree heights.

In each of these 23 parcels, a systematic research of vegetative reproduction on the ashes established has been made (Photo 1c).

The ash seedlings presence in each of the 96 parcels with botanical transects, has been visually observed from two walking transects respectively covering the longest and shortest diagonals of the parcel (May 2004). This method has been used because of its better efficiency that botanical transect to detect ash seedling at the parcel level.

\section{Management practices intensity}

A major constraint of in situ studies dealing with grazing activities is to evaluate the stocking rate which is generally expressed as a function of the number of grazing animal per surface unit and time unit. But the amount of herbage really taken off by the grazing animals depends upon a lot of diversified factors out of reach in the present study e.g. grazing behaviour, nutritional status of animals, quality and quantity of extra feedings, available herbage when entering the parcel, etc.). A second constraint is to evaluate the parcel production especially under continuous grazing situations. This supposes to put exclosures in each parcel to measure aerial biomass production out of grazing which considering the parcel number is a particularly heavy trial.

To overcome these difficulties, biomass production and biomass removal in the managed parcels i.e. the mown and/or grazed grasslands, have been evaluated indirectly from their botanical composition using a calibrated reference model established by Balent (1991) in an other Pyrenean valley. This model is based on the comparison of the botanical composition of a set of permanent grasslands differing in biomass production and biomass removal (Figure 1). Correspondence Analysis (CA Model) ordinates the parcels according to their biomass production (CA F1 axis) and the amount of biomass removal from both grazing animal and hay-making (CA F2 axis) along two orthogonal axes. CA model axes have been calibrated with external data. Biomass production has been estimated from $\mathrm{N}, \mathrm{P}$ and $\mathrm{K}$ concentration in plants which has been proved to be correlated to dry matter production (Duru et al. 1994). Biomass removal has been estimated by pooling the results from direct measurement of grazing intake on the study territory and from survey data on hay-meadow yields (Balent 1991). The intensity of use is approached through the ratio between biomass removal and biomass production as shown on Figure 1. Calibration, validation and confrontation with theory have confirmed the overall quality of this empirical model, established from plant communities in equilibrium with management (Balent 1991).

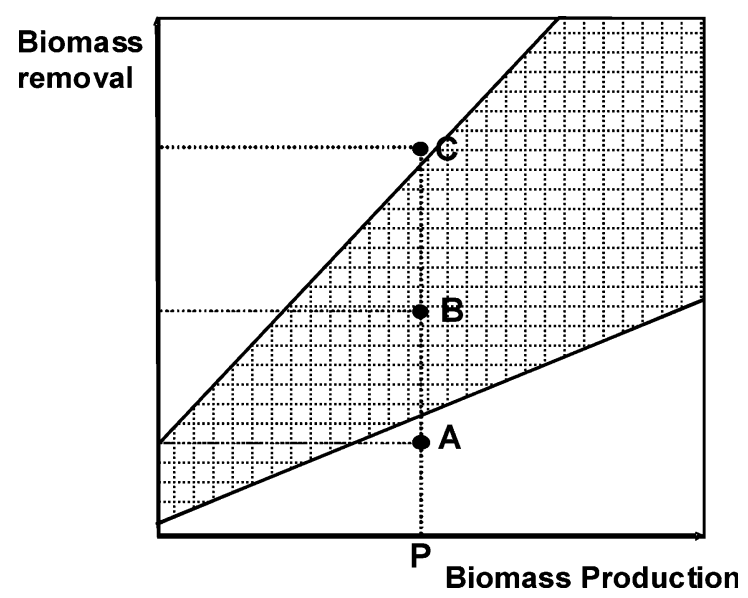

Figure 1. Reference model to compare the relationships between grassland biomass production and grassland biomass removal from grassland botanical composition (from Balent 1991). For a given level of biomass production (P), there is a range of possible levels of biomass production. In $\mathrm{A}$ a low percentage of produced biomass is removed leading to biomass accumulation (under utilisation); in $\mathrm{C}$ all the produced biomass is removed leading to the development of bare soil patches (over utilisation); B is an intermediate and widely observed situation. Oblique lines correspond to constant values of the biomass removal/biomass production ratio. 


\section{Data analyses}

The data matrix (96 transects $\times 199$ species abundance) has been analysed with a Correspondence Analysis (CA). We did not enter Fraxinus excelsior in this analysis to avoid confusion in transects' ordination between the invasive species and the invaded communities. CA is a well-known indirect gradient analysis method producing a reciprocal ordination of species and sample units (Hill 1973; Prodon and Lebreton 1981; Thioulouse and Chessel 1992). This analysis was performed running ADE4 library (Thioulouse et al. 1997) under the $\mathrm{R}$ environment (Ihaka and Gentleman 1996).

The relationships between ash patterns and explicative variables (Table 1) have been explored using different statistical methods. Simple linear regression has been used to evaluate the correlation between the first axis of the CA and the abundance of ash on transect and, height, density and mean age of ashes in the parcel. Chi-square test has been used to evaluate the importance of each land-use type in the four groups of ash colonization stages and to evaluate the importance of each land-use type upon ash presence/absence in the 90 grasslands. $T$-test has been used to compare differences in each grassland community characteristic (TSR, LR and SR50) between ash pres-

Table 1. Summary of the different patterns of ash distribution and the different explicative variables described above and used in the data analyses.

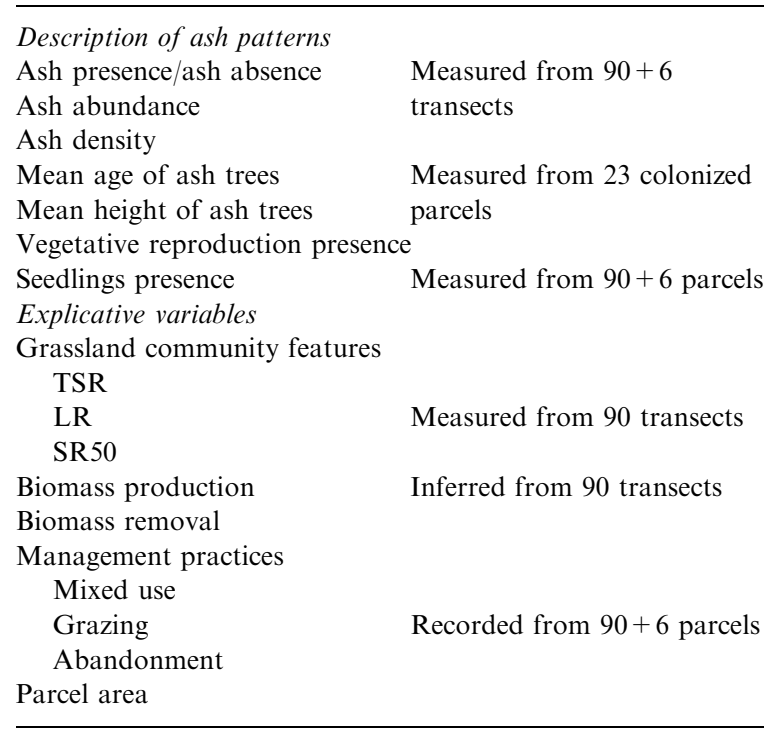

ence/absence in the 90 grasslands and has been used to compare differences in each CA model axes (biomass production and biomass removal) between ash presence/absence in the 90 grasslands on the one hand and between ash seedlings presence/absence in the 90 grasslands in the other hand. A one way analysis of variance (ANOVA) has been used to test the relationships between ash abundance and management practices (mixed use, grazing alone), to test the relationships between parcel area and the four groups of main stages of ash colonization and management practices, and test the relationships between management practices and each grassland community characteristic. All these methods have been run using SYSTAT 9 software (1999).

We performed a passive ordination in the CA model described previously of the 90 grasslands from their plant species composition and species scores on the two first axes of the model using the transition formula of CA (Benzécri 1973).

\section{Results}

\section{General patterns of ash distribution}

The first axis (F1) of the CA run on the 96 transects $\times 199$ plant species table has an eigenvalue $\left(\lambda_{\mathrm{F} 1}=0.57\right)$ corresponding to a relatively high canonical correlation between transects and species ordinations $\left(r_{\mathrm{F} 1}=\lambda_{\mathrm{F} 1}^{-1 / 2}=0.75\right)$. This is indicating a strong ecological gradient. Typical species of managed grasslands (Lolium perenne, Dactylis glomerata, etc.) are found at the negative pole of the gradient when understorey species (e.g. Stellaria holostea and Hedera helix), and nitrophilous species (e.g. Urtica dioica, Geranium robertianum) are at the positive pole (Figure 2). Ordination of grasslands along F1 axis is significantly and positively correlated to the increasing abundance of ashes from transects data, $(n=96$, $\left.r^{2}=0.73, p<0.001\right)$ and to the mean height of ash trees $\left(n=23, r^{2}=0.47, p<0.001\right)$. F1 has no significant correlation with mean age of ash trees $\left(n=23, r^{2}=0.14, \mathrm{NS}\right)$ and with ashdensity $(n=23$, $\left.r^{2}=0.048, \mathrm{NS}\right)$.

Four types of grasslands according to ash main stages of colonization (see legend of Figure 2) have been represented on the Figure 2. They differ in 


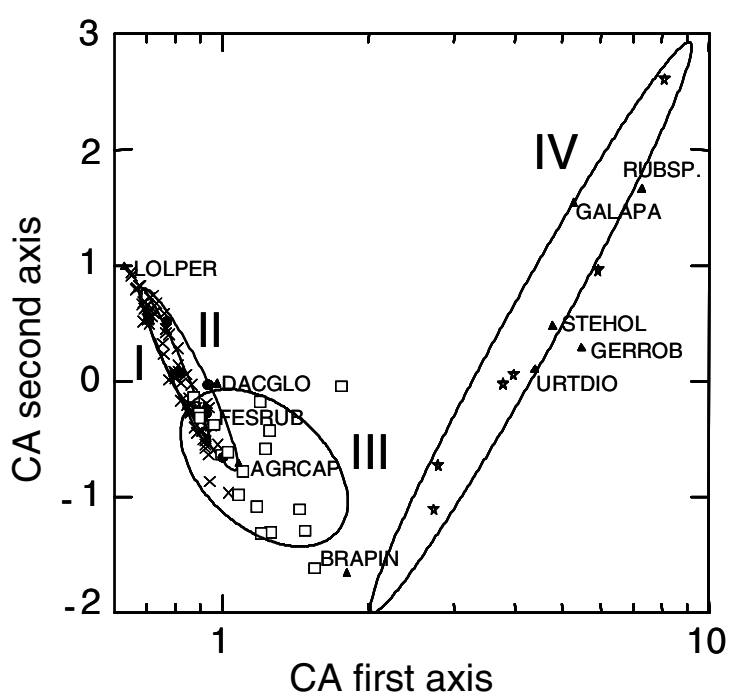

Figure 2. Ordination of the 96 transects and some representative plant species along the two first axes of the Correspondence Analysis performed on the vegetation data table. The four ellipses (power $=0.60$ ) indicate the dispersion of grasslands according to ash main stages of colonization ( $\mathrm{I}=$ no ash, $\mathrm{II}=$ only presence of ash seedlings, $\mathrm{III}=$ established trees in grasslands, IV = young forest stands). Crosses $(\times)$ are parcels of group I, dots (O) are parcels of group II, squares ( $\square$ ) are parcels of group III and stars (低) are parcels of group IV. LOLPER $=$ Lolium perenne, $\mathrm{AGRCAP}=$ Agrostis capillaris, DACGLO $=$ Dactylis glomerata,$\quad$ FESRUB $=$ Festuca rubra, $\mathrm{BRAPIN}=$ Brachypodium pinnatum, $\mathrm{URTDIO}=$ Urtica dioica, $\mathrm{STEHOL}=$ Stellaria holostea, $\mathrm{GERROB}=$ Geranium robertianum, $\mathrm{RUBSP}=$ Rubus species, GALAPA $=$ Galium aparine (Species are represented by a triangle $(\boldsymbol{\Lambda})$ ).

their management practices (Table 2). Most of the grasslands without ash (group I) are both mown and grazed. Mixed use is also dominant in the grasslands where ash seedlings were recorded on

Table 2. Pearson $\chi^{2}$ of the different groups (I-IV) and the different management practices (Mixed use, grazing alone and abandonment).

\begin{tabular}{lcclr}
\hline $\begin{array}{l}\text { Vegetation } \\
\text { types }\end{array}$ & \multicolumn{3}{l}{ Management practices } \\
\cline { 2 - 5 } & Mixed use & $\begin{array}{l}\text { Grazing } \\
\text { alone }\end{array}$ & Abandonment & Total \\
\hline I & $\mathbf{5 2}$ & 13 & 0 & 65 \\
II & $\mathbf{5}$ & 1 & 0 & 6 \\
III & 1 & $\mathbf{1 8}$ & 0 & 19 \\
IV & 0 & 1 & $\mathbf{5}$ & 6 \\
Total & 58 & 33 & 5 & 96 \\
\hline
\end{tabular}

Value $=117.980, \mathrm{df}=6$ and $p<0.001$. botanical transects (group II). Grazing alone is dominant in the grasslands of the group III and abandonment is dominant in the former grasslands of the group IV. The parcel areas do not present variations between these four groups $(n=96, F$-ratio $=0.436, \mathrm{NS})$ as well as between the three management practices $(n=96, F$-ratio $=0.97$, NS).

The CA biplot (Figure 2) also shows that the botanical composition of the herbaceous layer of young forest stands which is developing on abandoned grasslands (6 parcels of type IV) is characterised by understorey species and strongly differs from typical managed grasslands (groups I-III). Afterwards, we only consider the colonization process on the managed grasslands i.e. the 90 transects of the groups I-III.

\section{Presence/absence of ash in grasslands and plant communities' characteristics}

There is no significant relationship between the presence-absence of ash in the botanical transect and the total specific richness (TSR) $(n=90$, $t=-1.58$, NS). On the other hand, high values of SR50 are linked to the ash presence $(n=90$, $t=-4.03, p<0.001)$ i.e. the community heterogeneity is positively linked to ash presence. The mean species richness on each point (LR) is negatively $(n=90, t=2.14, p<0.05)$ linked with the presence of ash.

\section{Management types: mixed use versus grazing alone}

The abundance of ash is significantly higher in only grazed parcels compared to mixed used parcels $(n=90, F=23.65, p<0.001)$. In only grazed grasslands ash is significantly present compared to grasslands which are both mown and grazed $\left(n=90, \chi^{2}\right.$ value $\left.=22.93, p<0.001\right)$. In mixed used grasslands ash is significantly absent compared to grasslands which are only grazed $\left(n=90, \chi^{2}\right.$ value $=24.34, p<0.001$ ) .

\section{Management practices intensity}

The passive ordination of the 90 transects in the CA Model (Figure 3a) shows that grasslands are 
Figure 3. Passive ordination of the 90 grassland parcels in the Correspondence Analysis Model. (a) Plusses (+) are parcels mixed used and stars ( 5 ) are parcels only grazed (b) Triangles $(\triangle)$ are parcels without ash seedling and dots $(\bullet)$ are parcels with ash seedlings (c) Crosses $(\times)$ are parcels without established ash (groups I and II of the CA), squares ( $\square$ ) are parcels with only established ashes (group III) and filled squares (ם) are parcels where the presence of ash vegetative reproduction has been observed among the ashes established. The area located above the upper line is the over utilization field and the area located under the lower line is the under utilization field. Between the two lines is located the domain of usually observed intensity of grassland utilization. The doted line represents a threshold of intensity of use (ratio biomass removal/biomass production) above which the ash cannot establish.

widely distributed along the two axes indicating an important diversity in grassland management conditions in our data set. As expected, mixed used grasslands appear to be more intensive than only grazed.

On Figure 3b we can observe that ash seedlings are present in most of the 90 parcels independently of the biomass production axis $(n=90, t=0.089$, NS) and of the biomass removal axis $(n=90$, $t=1.476$, NS). On Figure $3 \mathrm{c}$ we can observe that for a given level of biomass production established ash trees are preferentially found in only grazed grassland with a lower level of biomass removal i.e. low management intensity. The presence of established ash trees is negatively linked to the biomass removal axis $(n=90, t=5.79, p<0.001)$ and independent of the biomass production level inferred from the CA model $(n=90, t=-0.86$, NS). We have drawn an eye adjusted threshold of intensity of use which marks the limit between parcels without and with established ashes. In this same figure, we can observe that the parcels with ash vegetative reproduction are located just under this threshold.

\section{Relationships between management practices and community features}

Some grassland vegetation characteristics in parcels exhibits contrasted patterns of variations when confronted with the management practices. The local richness (LR) is significantly higher in mixed use parcels than in only grazed ones $(n=90$, $F=17.04, \quad p<0.001)$. Community heterogeneity (SR50) is significantly higher in only grazed parcels compared to mixed used ones $(n=90, F=28.5$,
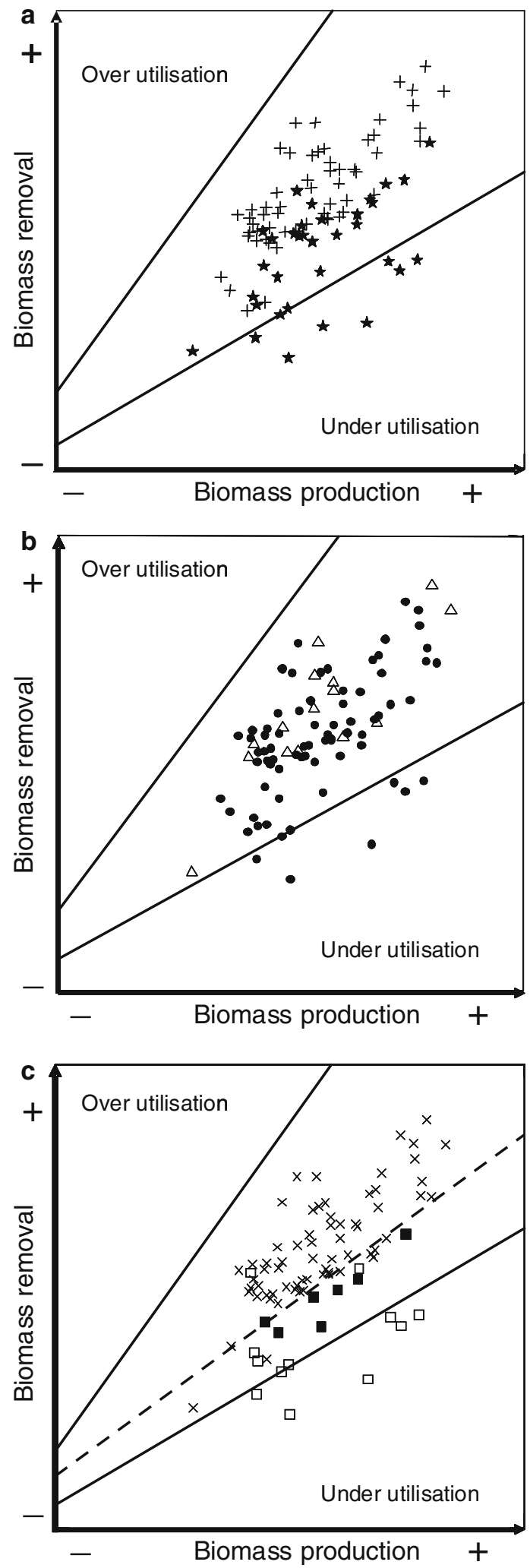
$p<0.001)$. At the opposite, the total specific richness (TSR) is not significantly different between mixed used and only grazed parcels $(n=90$, $F=0.35$, NS).

\section{Discussion}

\section{Patterns of ash colonization}

It is widely admitted that colonization in grasslands is determined by three main factors: dispersal constraints, environmental constraints and community features (Belyea and Lancaster 1999). Introducing this work, we have hypothesized that in our study site the ash propagule pressure was high and spatially evenly distributed. The presence of ash seedlings in most of the grasslands independently of the management type and intensity confirms this hypothesis. Furthermore, the few grassland without ash seedlings are all grazed during spring time before to be mown thereby we cannot exclude that seedlings have been present on these grasslands in early spring before the grazing period. As a matter of fact, the ash colonization is not limited by the propagule arrival defined by Williamson (1996) as the first environmental filter to invasion.

When we examine in detail the CA first axis (F1) we can interpret it as a secondary successional gradient of ash colonization. However, it cannot be interpreted as a chronosequence because the results on the age of the ash stands refute this hypothesis. So, we can consider it as a 'physiognomic' or 'visual' secondary succession according to the height and abundance of ashes established in the grasslands. The result is that some parcels of the group III have about the same age but a smaller height than some parcels of the group IV.

Our results confirm that key factors explaining the importance of ash establishment and expansion are likely to be found in the management practices, i.e. the type of land uses and its intensity because they are part of environmental constraints, but they may also influence community features.

\section{Intensive management practices prevent the} establishment of ash seedlings in the grassland

Despite the fact that ash is able to germinate in mown grassland excepting in those with early spring grazing, mowing appears to delete totally every year the ash seedlings. Like mixed use, when grazing (alone) intensity increases, this factor is likely to become a constraint, deleting seedlings in a similar way. The mixed use or a high grazing intensity (which correspond to a high intensity of use in the CA model) can be considered as a mechanical barrier to ash establishment. McPherson (1993) has simulated the effects of herbivory on woody seedling (Quercus emoryi) establishment by experimental clipping. He found that seedlings did not survive after being clipped more than twice. Ash seedling establishment was studied in grazed pastures by Hester et al. (1996) who showed that recruitment was more important in the low grazing intensity plots than in the medium grazing intensity plots. Indeed, our results show that the limit between grasslands with and without established ashes correspond to a threshold in the intensity of use (biomass removal/biomass production ratio). This is consistent with the conclusions of Jeltsch et al. (1997) stating that '...the grazing of grasses beyond a certain threshold led to an almost deterministic increase in shrub cover'. However, such threshold would only be detected if grazing pressure and productivity are accurately measured which is not so easy in natural conditions. In that way, the use of an empirical model based on calibrated and validated data, is very helpful to detect this threshold.

\section{Factors allowing the establishment of ash seedlings in the grassland}

Our results show that ash presence in grasslands is connected to grazing activities. A grazing intensity lower than the threshold displayed by the CA model (a more or less extensive grazing), creates heterogeneities within the grassland community such as patches of herbage neglected by grazing animals. These tussocks are suitable for woody seedlings establishment by protecting young seedlings from grazing (MacCarthy and Facelli 1990). Moreover, we hypothesize that they constitute suitable habitat conditions for shade tolerant ash seedlings and juvenile stages (Grime et al. 1988; Marigo et al. 2000). Therefore, our observations of seedlings presence in a high layer of vegetation before the hay cutting or in neglected areas of grazed grasslands support this hypothesis. 
García-Robledo and Murcia (2005) working on the habitat susceptibility to invasion by Chinese ash (Fraxinus chinensis) have found that 'Chinese ash seedlings were able to grow through a thick mat of grasses'. The fact that community heterogeneity (SR50) is positively linked with the presence of established ash trees is in line with our previous assumption on the ash seedling establishment.

However this process is probably not a generalized rule because herbaceous biomass may have contrasted role on the success of woody colonization. The work of De Steven (1991) showing that the herbaceous vegetation facilitates the emergence of woody species with large seeds (Acer rubrum and Fraxinus americana) supports our hypothesis. Bellingham and Coomes (2003) also found that resident tussocks close to Scotch broom (Cytisus scorparius) seedlings increased their survival. Other works carried out on legume trees suggested that herbaceous layer has no effect on the emergence or growth of the invaders (Brown et al. 1998; Brown and Archer 1999). Some authors have shown that herbaceous vegetation inhibits woody establishment due to competition between grasses and woody seedlings for resource access (Van Auken 2000; Mazia et al. 2001; Castro et al. 2002). In these last studies, intensive grazing acts favourably on the woody colonization creating gaps in the herbaceous vegetation where tree seedlings can emerge and survive (Bokdam and Gleichman 2000; Briggs et al. 2002). In the studies showing a positive effect of herbaceous biomass on woody seedlings survival (De Steven 1991; Bellingham and Coomes 2003), the seedlings are palatable to grazing animals like ash is and are vulnerable to browsing damage. In the early stage of their development herbage biomass is probably acting like a protection against grazing (Kuiters and Slim 2003; Rousset and Lepart 2003).

Many experimental or theoretical studies supported the idea that species richness was a tangible surrogate for community resistance to invasion (Tilman and Downing 1994; MacCann 2000). The diversity/invasibility hypothesis (Elton 1958) is a real discording topic today. A lot of experimental studies report a negative relationship (Tilman 1997; Knops et al. 1999; Kennedy et al. 2002) whereas most of studies in situ report a positive relationship (Planty-Tabacchi 1995; Stohlgren et al. 1999; Stromberg et al. 2001). On the one hand, authors wanted to test experimentally only the diversity effect and on the other hand the authors wanted to test the diversity in a local context. However, diversity alone cannot explain the invasibility which is dependent of a set of diversified factors (Prieur-Richard and Lavorel 2000; Kolb et al. 2002). Our field data showed a low relationship between the presence of ash and low local species richness while no trend was associated to the species richness measured at the community level. Similar results were depicted at the neighbourhood level in a microcosm grassland experiment (Dukes 2002) and opposite results were observed by Stohlgren et al. (2003) who found that species richness at the neighbourhood level is not a barrier to the invader. As previously discussed it is difficult to draw a definitive conclusion on the specific role of species richness as the local richness is strongly linked with management practices (higher in the mown parcels).

\section{Management practices favouring or inhibiting the ash expansion}

After establishment, ash expansion depends upon the management practices as well specially on grazing intensity which is controlling the possibility of ash trees to growth normally in height and diameter. In case of total cessation of grazing (abandonment of the parcel) young woodland stands is developing rapidly (Photo 1a). The youngest of these stands has about 15 years with a mean height of $6 \mathrm{~m}$ and the oldest about 24 years with a mean height of $15 \mathrm{~m}$. At this stage of the growth we can suppose that the only 'natural brake' to ash expansion is intraspecific competition as suggested by Cooke (1998). In case of persistence of grazing activity, patterns of growth are depending upon grazing intensity. Under a relatively high grazing intensity i.e. around the threshold highlighted by the CA model, we have observed that the established ash trees were developing subterranean vegetative suckers (Photo 1c.) (Grime et al. 1988; Marigo et al. 2000) which should be considered as a response to intense disturbance (Pornon et al. 1997; Barsoum 2001). Visually, this type of grassland presents trees with a slower growth in height and diameter compared with undisturbed growing trees. For example, we have found a 16 years old tree with a height of $15 \mathrm{~cm}$. Moreover, under low grazing intensity, 
height tree in parcels is highly heterogeneous (Photo 1b). For example in the same parcel we have found a 18 years old tree measuring $1.5 \mathrm{~m}$ and a 16 years old tree measuring $3.85 \mathrm{~m}$ or in another parcel two 21 years old trees measuring respectively $5.5 \mathrm{~m}$ and $15 \mathrm{~m}$.

Whichever of the grazing intensity is, ash is able to develop a compensatory growth after a complete defoliation by grazing or browsing animals (Hester et al. 1996, 2004; Strauss and Agrawal 1999; Collin et al. 2000). The unanswered question in our study is about the mechanisms underlying this process and the few examples available in the literature are dealing with patterns. Harmer (2001) has observed that 'established seedlings that are $>30 \mathrm{~cm}$ tall can survive several years of severe browsing under the shade of a 50\% canopy cover or more'. Cooke (1998) studying the effects of deer browsing damage on survival and regrowth performance of coppiced ash has found that "ash survival was related to regrowth performance during the year following coppicing' i.e. when ash sprouting are about $2 \mathrm{~m}$ height. However, these studies have taken place in forest conditions not in grassland conditions.

\section{Conclusion}

The successful establishment of seedlings is an important element of grasslands colonization by ash. Management practices are determinant in this transition which occurs in the first months after ash germination either by the direct removal of seedling or the indirect filtering through community features (herbaceous biomass and heterogeneity). Herbaceous biomass as the result of low grazing intensity facilitates the establishment of ash by protecting seedlings from defoliation. Management appears to have a major influence on ash growth after it is established in the grassland. A high intensity grazing seems to reduce remarkably the growth of ash tree in height and diameter whereas a low intensity grazing disturbs more or less intensively the growth of trees.

From a management perspective, the 'a priori' control of ash expansion seems to be effective through direct disturbance intensity (i.e. rate of biomass removal or frequency of cutting) in the first months following germination.
The evaluation of the real importance of the vegetative strategy in the colonization process is difficult. Does this phenomenon play an active part in the expansion process? Does it occur only in a few parcels in particular conditions or is it a generalized and widely spread strategy? The conditions for the apparition of the vegetative reproduction are unknown in terms of both disturbance intensity and/or species plasticity. Moreover, the ash compensatory growth in grazed grasslands conditions is unknown. So, further work is to be developed in two directions: a study of the regeneration niche of ash germination and establishment with an experimental test between conditions of grazing and herbaceous biomass vs. conditions of biomass removal and gap creation; a study of the demographic and genetic structure of ash population and its variability within and between plots to evaluate the relative importance of the sexual vs. vegetative reproduction in ash strategies of expansion.

\section{Acknowledgements}

We thank Marie Degeilh, Victor Hausard, Etienne Nadal, Laurent Raison and Jerome Willm for their contribution to the botanical survey, Laurent Burnel for its contribution to tree measurements, Laurent Raison for its contribution to soil description and field surveys, and Sylvie Ladet for GIS assistance. We thank Marianne Fontova, Estelle Cantala and Anne Mottet for providing unpublished data on respectively ash dendrometry, site history and management practices. We are grateful to Annick Gibon for fruitful discussions on the relationships between Pyrenean farming systems dynamics and ash colonization. We thank the Pyrenees National Park and INRA for financial support (Grant INRA-PNP 2002-45-S).

\section{References}

Archer S., Scifres C., Bassham C.R. and Maggio R. 1988. Autogenic succession in a subtropical savanna: conversion of grassland to thorn woodland. Ecol. Monogr. 58: 111-127.

Austrheim G., Gunilla E., Olsson A. and Grontvedt E. 1999. Land-use impact on plant communities in semi-natural subalpine grasslands of Budalen, central Norway. Biol. Conserv. 87: $369-379$. 
Balent G. 1991. Construction of a reference frame for studying the changes in species composition in grassland. Options Méditerranéennes 15: 73-81.

Barrère P., Bois J.P., Soulé J.C. and Ternet Y. 1980. France geological map 1/50 000: Argeles-Gazost sheet XVI-47. Ministère de l'Industrie. Bureau de Recherches Géologiques et Minières. Service Géologique National Edition.

Barsoum N. 2001. Relative contributions of sexual and asexual regeneration strategies in Populus nigra and Salix alba during the first years of establishment on a braided gravel bed river. Evol. Ecol. 15: 255-279.

Baize D. and Girard M.C. 1995. coord. Référentiel Pédologique. INRA, Paris.

Bellingham P.J. and Coomes D.A. 2003. Grazing and community structure as determinants of invasion success by Scotch broom in a New Zealand montane shrubland. Diversity Distribut. 9: 19-28.

Belyea L.R. and Lancaster J. 1999. Assembly rules within a contingent ecology. Oikos 86: 402-416.

Benzécri J.P. 1973. L'Analyse des Données. Tome 2: L'Analyse des Correspondances. Dunod, Paris.

Bokdam J. and Gleichman J.M. 2000. Effects of grazing by free-ranging on vegetation dynamics in a continental northwest European heathland. J. Appl. Ecol. 37: 415-431.

Briggs J.M., Knapp A.K. and Brock B.L. 2002. Expansion of woody plants in tallgrass prairie: a fifteen-year study of fireand fire-grazing interaction. Am. Midl. Nat. 147: 287-294.

Brown J.R. and Archer S. 1989. Woody plant invasion of grasslands. Establishment of honey mesquite (Prosopisglandulosa var glandulosa) on sites differing in herbaceous biomass and grazing history. Oecologia (Berlin) 80: 19-26.

Brown J.R., Scanlan J.C. and MacIvor J.G. 1998. Competition by herbs as a limiting factor in shrub invasion in grassland: a test with different growth forms. J. Veg. Sci. 9: 829-836.

Brown J.R. and Archer S. 1999. Shrub invasion of grassland: recruitment is continuous and not regulated by herbaceous biomass or density. Ecology 80: 2385-2396.

Castro J., Zamora R. and Hodar J. 2002. Mechanisms blocking Pinus sylvestris colonization of Mediterranean mountain meadows. J. Veg. Sci. 13: 725-731.

Collin P., Epron D., Alaoui-Sosse B. and Badot P.M. 2000. Growth responses of common ash seedlings (Fraxinus excelsior L.) to total and partial defoliation. Ann. Bot. 85: 317-323.

Cooke A. 1998. Survival and regrowth performance of coppiced ash (Fraxinus excelsior) in relation to browsing damage by muntjac deer (Muntiacus reevesi). Q. J. For. 92: 286-290.

Daget P. and Poissonet J. 1971. Une méthode d'analyse phytologique des prairies. Critères d'application. Annl. Agron. 22: $5-41$.

De Steven D. 1991. Experiments on mechanisms of tree establishment in old-field succession: seedling emergence. Ecology 72: 1066-1075.

Duchaufour P. 1983. Pédologie. Tome 1: Pédogenèse et classification 2èmend ed. Masson, Paris.

Duru M., Balent G. and Langlet A. 1994. Mineral nutritional status and botanical composition of pastures. I. Effect on herbage accumulation. Eur. J. Agron. 3: 43-51.

Dukes J.S. 2002. Biodiversity and invasibility in grassland microcosms. Oecologia 126: 563-568.
Elton C.S. 1958. The ecology of invasion by animals and plants Chapman \& Hall, Londonin.

García-Robledo C.A. and Murcia C. 2005. Comparative habitat susceptibility to invasion by Chinese ash (Fraxinus chinensis: Oleaceae) in a tropical Andean landscape. Biol. Invasions 7: 405-415.

Garcia-Ruiz J.M., Lasanta T., Ruizflano P., Ortigosa L., White S., Gonzalez C. and Marti C. 1996. Land-use changes and sustainable development in mountain areas: a case study in the spanish pyrenees. Land. Ecol. 11: 267-277.

Gibon A. and Balent G. 2004. Landscape on the French side of the western and central Pyrenees. In: Bunce B., Howard D. and Correia T.P. (eds), Iale, UK.

Grime J.P., Hodgson J.G. and Hunt R. 1988. Comparative plant ecology: a functional approach to common British species. Unwin Hyman, London, UK.

Harmer R. 2001. The effect of plant competition and simulated summer browsing by deer on tree regeneration. J. Appl. Ecol. 38: $1094-1103$.

Hester A.J., Mitchell F.J.G. and Kirby K.J. 1996. Effects of season and intensity of sheep grazing on tree regeneration in a British upland woodland. For. Ecol. Manage. 88: 99-106.

Hester A.J., Millard P., Baillie G.J. and Wendler R. 2004. How does timing of browsing affect above- and below-ground growth of Betula pendula, Pinus sylvestris and Sorbus aucuparia?. Oikos 105: 536-550.

Hill M.O. 1973. Reciprocal averaging: an eigenvector method of ordination. J. Ecol. 61: 237-249.

Hooper D.U. and Vitousek P.M. 1997. The effects of plant composition and diversity on ecosystem processes. Science 277: $1302-1305$.

Ihaka R. and Gentleman R. 1996. R: a language for data analysis and graphics. J. Comput. Graph. Stat. 5: 299-314.

Jeltsch F., Milton S.J., Dean W.R.J. and Vanrooyen N. 1997. Analysing shrub encroachment in the southern Kalahari: a grid-based modelling approach. J. Appl. Ecol. 34: 1497-1508.

Keddy P.A. 1992. Assembly and response rules: two goals for predictive community ecology. J. Veg. Sci. 3: 157-164.

Kennedy T.A., Naeem S., Howe K.M., Knops J.M.H., Tilman D. and Reich P.B. 2002. Biodiversity as a barrier to ecological invasion. Nature 417: 636-638.

Knops J.M.H., Tilman D., Haddad N.M., Naeem S., Mitchell C.E., Haarstad J., Ritchie M.E., Howe K.M., Reich P.B., Siemann E. and Groth J. 1999. Effects of plants species richness on invasion dynamics, disease outbreaks, insect abundances and diversity. Ecol. Lett. 2: 286-293.

Kolb A., Alpert P., Enters D. and Holzapfel C. 2002. Patterns of invasion within a grassland community. J. Ecol. 90: 871-881.

Kuiters A.T. and Slim P.A. 2003. Tree colonisation of abandoned arable land after 27 years of horse-grazing: the role of bramble as a facilitator of oak wood regeneration. For. Ecol. Manage. 181: 239-251.

Lauga J. and Joachim J. 1987. L'échantillonnage des populations d'oiseaux par la méthode des E.F.P.: intérêt d'une étude mathématique de la courbe de richesse cumulée. Acta Oecol., Oecol. Gen. 8: 117-124.

Lett M.S. and Knapp A.K. 2003. Consequences of shrub expansion in mesic grassland: resource alterations and graminoid responses. J. Veg. Sci. 14: 487-496.

Lodge D.M. 1993. Biological invasions: lessons for ecology. Trends Ecol. Evol. 8: 133-137. 
MacCann K.S. 2000. The diversity-stability debate. Nature 405: $228-233$

MacCarthy B.C. and Facelli J.M. 1990. Microdisturbances in oldfields and forests: implications for woody seedling establishment. Oikos 58: 55-60.

MacDonald A., Crabtree J.R., Wiesinger G., Dax T., Stamou N., Fleury Ph., Gutierrez Lazpita J. and Gibon A. 2000. Agricultural abandonment in mountain areas of Europe: environmental consequences and policy response. J. Environ. Manage. 59: 47-69.

Marigo G., Peltier J.P., Girel J. and Pautou G. 2000. Success in the demographic expansion of Fraxinus excelsior L. Trees Struct. Funct. 15: 1-13.

Mazia C.N., Chaneton E.J., Ghersa C.M. and Leon J.C. 2001. Limits to tree species invasion in pampean grassland and forest plant communities. Oecologia 128: 594-602.

McPherson G.R. 1993. Effects of herbivory and herb interference on oak establishment in a semi-arid temperate savanna. J. Veg. Sci. 4: 687-692.

Moleele N.M., Ringrose S., Matheson W. and Vanderpost C. 2002. More woody plants? the status of bush encroachment in Botswana's grazing areas. J. Environ. Manage. 64: $3-11$.

Moyle B.M. and Light T. 1996. Biological invasions of fresh water: empirical rules and assembly theory. Biol. Conserv. 78: $149-161$.

O'Connor T.G. 1994. Composition and population responses of an african savanna grassland to rainfall and grazing. J. Appl. Ecol. 31: 155-171.

Pasche F., Armand M., Gouaux P., Lamaze T. and Pornon A. 2004. Are meadows with high ecological and patrimonial value endangered by heathland invasion in the French central Pyrenees. Biol. Conserv. 118: 101-108.

Planty-Tabacchi A.M., Tabacchi E., Naiman R.J., Deferrari C. and Decamps H. 1995. Invasibility of species-rich communities in riparian zones. Conserv. Biol. 10: 598-607.

Pornon A., Escaravage N., Till-Bottraud I. and Doche B. 1997. Variation of reproductive traits in Rhododendron ferrugineum L. (Ericaceae) populations along a successional gradient. Plant Ecol. 130: 1-11.

Prach K., Leps J. and Michalek J. 1996. Establishment of Picea abies seedlings in a central European mountain grassland: an experimental study. J. Veg. Sci. 7: 681-684.

Prévosto B., Hill D.R.C. and Coquillard P. 2003. Individualbased modelling of Pinus sylvestris invasion after grazing abandonment in the French Massif Central. Plant Ecol. 168: $121-137$

Prieur-Richard A.H. and Lavorel S. 2000. Invasions: the perspective of diverse plant communities. Aust. Ecol. 25: 1-7.

Prodon R. and Lebreton J.D. 1981. Breeding avifaune of a mediterranean succession: the Holm oak and cork oak series in the eastern Pyrenees. I, Analysis and modelling of the structure gradient. Oikos 37: 21-38.
Roques K.G., Oconnor T.G. and Watkinson A.R. 2001 Dynamics of shrub encroachment in an african savanna: relative influences of fire, herbivory, rainfall and density dependence. J. Appl. Ecol. 38: 268-280.

Rouget M. and Richardson D.M. 2003. Inferring process from pattern in plant invasions: a semimechanistic model incorporating propagule pressure and environmental factors. Am. Nat. 162: 713-724.

Rousset O. and Lepart J. 2003. Neighbourhood effects on the risk of an unpalatable plant being grazed. Plant Ecol. 165: 197-206.

Skowno A.L., Midgley J.J., Bond W.J. and Balfour D. 1999. Secondary succession in Acacia nilotica (L.) savanna in the Hluhluwe Game Reserve, South Africa. Plant Ecol. 145: $1-9$.

Stampfli A. 1991. Accurate determination of vegetation change in meadows by successive poinst quadrat analysis. Vegetatio 96: $185-194$.

Stohlgren T.J., Binkley D., Chong G.W., Kalkhan M.A., Schell L.D., Bull K.A., Otsuki Y., Newman G., Bashkin M. and Son Y. 1999. Exotic plant species invade hot spots of native plant diversity. Ecol. Monogr. 69: 25-46.

Stohlgren T.J., Barnett D.T. and Kartesz J.T. 2003. The rich get richer: patterns of plant invasions in the United States. Front. Ecol. Environ. 1: 11-14.

Strauss S.Y. and Agrawal A.A. 1999. The ecology and evolution of plant tolerance to herbivory. Trends Ecol. Evol. 14: $179-185$.

Stromberg M.R., Kephart P. and Yadon V. 2001. Composition, invasibility, and diversity in coastal california grasslands. Madroño 48: 236-252.

SYSTAT 1999. ^ 9.0 for Windows ${ }^{\circledR}$ Statistics I., SPSS, Chicago, USA edition. SPSS, Chicago, USA.

Thioulouse J. and Chessel D. 1992. A method for reciprocal scaling of species tolerance and sample diversity. Ecology 73: 671-680.

Thioulouse J., Chessel D., Doledec S. and Olivier J.M. 1997. ADE-4: a multivariate analysis and graphical display software. Stat. comput. 7: 75-83.

Tilman D. and Downing J.A. 1994. Biodiversity and stability in grasslands. Nature 367: 363-365.

Tilman D. 1997. Community invasibility, recruitment limitation, and grassland biodiversity. Ecology 78: 81 -92.

Tutin T.G., Heywood V.H., Burges N.A., Moore D.M., Valentine D.H., Walters S.M. and Webb D.A. 1983. The Flora Europaea. Cambridge, Cambridge University Press, Cambridge, UK.

Van Auken O.W. 2000. Shrub invasions of north american semiarid grasslands. Annu. Rev. Ecol. Syst. 31: 197-215.

Williamson M. 1996. Biological Invasions. Chapman and Hall edition London, UK.

Williamson M. and Fitter A. 1996. The varying success of invaders. Ecology 77: 1661-1666. 